\title{
THE THEOLOGICAL CONTROVERSY BETWEEN EUNOMIUS AND BASIL THE GREAT: A PHILOSOPHICAL APPROACH
}

\author{
Christos Terezis and Spyros P. Panagopoulos* \\ University of Patras
}

\begin{abstract}
In this paper we examine an aspect of the conflict between Eunomius of Cyzicus and Basil the Great, as it referred to supreme dogmatic matters, such as the relationships between the Persons of the Holy Trinity. This theological rupture appears in a period, during which Christian doctrines are composed at advanced levels of maturity, also with the development among other things of impressive leaps toward which had been attempted by Origen, who was basically also the founder of Christian Hermeneutics. We refer to the basic concept of the conflict, namely the epinoia, and we set it off through the ontological-epistemological knowledge-contrast of realism-idealism. Our research programme is based in part on the historical element, par excellence on the systematic. As to the specific object of analysis, our report will be limited to an outline text of Basil of Caesarea and our aim will be to draw it out in its full development, from one expression to the next. This is the sixth chapter of the first book from the treatise Against Eunomius.
\end{abstract}

KEY WORDS: Eunomius of Cyzicus, Basil the Great, epinoia, idealism, realism

\section{Introduction}

The controversy between Eunomius ${ }^{1}$ and the Cappadocian Fathers Basil the Great and Gregory of Nyssa was of particular concern to the theological thought of Byzantium during the 4 th century, as it referred to supreme dogmatic matters, such tor of School of Humanities and Social Sciences at the University of Patras, Greece. His main research interests are Neoplatonism (Proclus, Damascius, Syrianus) and Byzantine Philosophy and Theology (Maximus the Confessor, Dionysius the Areopagite). He is the author of over one hundred articles and six books. SPYROS P. PANAGOPOULOS is an independent scholar of Byzantine and Patristic studies in Patras, Greece, having studied Philology and Philosophy at the city's university. His research interests include Byzantine Philology, History, and Art, Patristics, and Church History until the fifteenth century. Having been invited to lecture in over thirty conferences and workshops in Greece and abroad, he is the author of two dozen academic papers and three monographs pending publication.

1 Eunomius (died c. 393), one of the leaders of the extreme or "anomean" Arians, who are sometimes accordingly called Eunomians, was born at Dacora in Cappadocia early in the 4th century. He studied theology at Alexandria under Aetius, and afterwards came under the influence of Eudoxius of Antioch, who ordained him deacon. On the recommendation of Eudoxius he was 
as the relationships between the Persons of the Holy Trinity. However, this specific controversy was not confined only to references to theological content, but also impinged on matters that were related to questions of philosophical presuppositions, mainly in the field of linguistic analysis, epistemology, ontology and cosmology. It was about dialectical reassessment of both a synthetic and systematic character, and so was not confined to theological ventures of a one-way type. The addition of these philosophical fields to the explosive theological investigation which developed, makes known with every perspicuity that the factors contributing to its development dominated to an advanced degree the philosophical problematic and had a sense of necessity for its timely use in theological analyses and synthetic judgements. Besides, the presence even of philosophical theories is also revealed by terminology which is used by both sides. The controversy in question has concerned both Greek and international research to an impressive degree quantitatively while texts with original analytical and post-analytical theories have also been written, which raised queries with reference to the content of divine substance-nature, of divine personshypostases and of divine activities. This research study of course is not without any scientific interest and makes known the multiplicity of meanings which are located

appointed bishop of Cyzicus in 360. Here his free utterance of extreme Arian views led to popular complaints, and Eudoxius was compelled, by command of the emperor, Constantius II, to depose him from the bishopric within a year of his elevation to it. During the reigns of Julian and Jovian, Eunomius resided in Constantinople in close intercourse with Aetius, consolidating a dissenting party and consecrating bishops. He then went to live at Chalcedon, from whence in 367 he was banished to Mauretania for harboring the rebel Procopius. He was recalled, however, before he reached his destination. In 383 the emperor Theodosius, who had demanded a declaration of faith from all party leaders, punished Eunomius for continuing to teach his distinctive doctrines, by banishing him to Halmyris in Scythia Minor. He afterwards resided at Chalcedon and at Caesarea in Cappadocia, from which he was expelled by the inhabitants for writing against their bishop Basil. His last days were spent at his birthplace Dacora, where he died about 393. His writings were held in high reputation by his party, and their influence was so much dreaded by the orthodox, that more than one imperial edict was issued for their destruction. Consequently his commentary on the Epistle to the Romans, mentioned by the historian, Socrates Scholasticus and his epistles, mentioned by Philostorgius and Photius, are no longer extant. His first apologetical work, written probably about 360 or 365 , has been entirely recovered from the famous refutation of it by Basil of Caesarea. A second apology, written before 379 exists only in the quotations given from it in a refutation by Gregory of Nyssa. The exposition of faith, called forth by the demand of Theodosius, is still extant, and has been edited by Valesius in his notes to Socrates of Constantinople, and by Ch. H. G. Rettberg in his Marcelliana. The teaching of the Anomoean School, led by Aetius and Eunomius, starting from the conception of God as Creator, argued that between the Creator and created there could be no essential, but at best only a moral, resemblance. The Eunomian heresy was formally condemned by the Council of Constantinople in 381. The sect maintained a separate existence for some time, but gradually fell away owing to internal divisions. After Eunomius died, Eutropius ordered that Eunomius' body be moved to Tyana and his books be burned. Eunomius treatises have been published by Richard Paul Vaggione, Eunomius. The Extant Works (Oxford: Oxford University Press, 1987).

PERICHORESIS $11.1(2013)$ 
in the controversy between Eunomius and the Cappadocian Fathers. ${ }^{2}$ Moreover, this theological rupture appears in a period, during which Christian doctrines are composed at advanced levels of maturity, also with the development among other things of impressive leaps toward which had been attempted by Origen, who was basically also the founder of Christian Hermeneutics. Such periods are since the authenticity of theoretical propositions and prevalence in the dialectical meeting of ideas are claimed by many sides. Indeed in a theological atmosphere, with clear extensions into questioning of existential structure, the assertion in question sometimes assumes a psychologically conflictual character, not only from the introducers of the theses-interpretations but also from their receivers. Indeed sometimes it is invested also with ideological content. Furthermore, in the 4th century religious anxieties determined to a greater extant the theoretical questions which had already been posed at the outset of the late Hellenistic and early Byzantine period, and not only in the Christian domain.

Our research undertaking, in a risky gamble to set it in succession in conceptual outlines, will set as a specific goal approximately the above issue to a special attestation, which has concerned in particular philosophical reflection on its historical development. We will deal with the basic concept of the conflict, namely the epinoia, ${ }^{3}$

For the Cappadocian-Eunomian dispute we refer you to the following studies: J. Danielou, "Eunome l'arien et l'exégèse néoplatonicienne du Cratyle", Revue des Études Grecques 69 (1956): 412-452; E. Vandenbusche, "La part de la dialectique dans la théologie d'Eunomius 'le technologue", Revue d'Histoire Ecclésiastique 40 (1944/45): 47-72; G. J. M. Bartelink, "Observations de saint Basile sur la langue biblique et théologique", Vigiliae Christiane 17 (1963): 85-104; KarlHeinz Uthemann, "Die Sprache der Theologie nach Eunomius vun Cyzicus", Zeitschrift für Kirchengeschichte 104.2 (1993): 143-175; Th. Dams, La controverse eunoméenne (Paris: Catholic Institut of Paris, 1952); E. Cavalcanti, Studi eunomiani (Roma: Pont. Instit. Orient. Stud., 1976); Philip Rousseau, "Basil of Caesarea, Contra Eunomium. The main preoccupations: The idea of salvation", The Idea of Salvation, ed. by D. W. Dockrill and R. G. Tanner (Newcastle: University of New England Press, 1988), 77-94; M. V. Anastos, "Basil's Kata Eunomiou. A critical analysis", Basil of Caesarea. Christian, Humanist, Ascetic, ed. by P. J. Fedwick (Toronto: Institute of Medieval Studies, 1981), 67-136; P. R. Vaggione, Eunomius. The Extant Works (Oxford: Oxford University Press, 1987); P. R. Vaggione, Eunomius of Cysicus and the Nicene Revolution (Oxford: Oxford University Press, 2000).

For the meaning of "epinoia" among others see also the following: A. Orbe, La Epinoia. Algunos preliminares historicos de la distinction kat' epinoian (Roma, 1955); E. C. E. Owen, "Epinoeō, epinoia and allied Words", JThSt 35 (1934): 368-376; Evanghélos Moutsopoulos, "Épinoia et imaginaire chez Gregoire de Nysse (CE II 172-195)", Gregory of Nyssa: Contra Eunomium II, ed. by Lenka Karfíková, Scot Douglass and Johannes Zachhuber (Leiden: Brill, 2007), 363-375. See also the studies by Theo Kobusch (3-20), Charalambos Apostolopoulos (239-245), John A. Demetrakopoulos (387-397), Tina Dolidze (445-459) and Tamara Aptsiauri (455-503) in the previous conference volume, about epinoia in both Basil the Great and Gregory of Nyssa. For the meaning of epinoia in Basil the Great see also the following: Mark DelCogliano and Andrew Radde-Galwitz (eds.), St. Basil of Caesarea. Against Eunomius (Washington, DC: The Catholic University of America Press, 2011), 38-55; Mark DelCogliano, Basil of Caesarea's Anti-Eunomian Theory of Names: Christian Theology and Late-Antique Philosophy in the Fourth-Century Trinitarian Controversy, Supplements to Vigiliae Christianae 103 (Leiden: Brill, 2010); Andrew Radde-Galwitz, Basil of Caesarea, 
and we will set it off through the ontological-epistemological knowledge-contrast of realism-idealism. In general conception, realism argues that external reality constitutes the only authentic objective data and imposes its constants on human thought, which is required to adjust, if possible, absolutely methods to be chosen and the conceptual structure that will result in its content and mobility, in the being and appearance of its pressure. On the other hand, idealism is based on a position of an a priori conceptual basis in human consciousness, which determines also the content of external objects, onto which in some way it sets categorical definitions, under the undeniable apprehension that these take almost no part in the shaping of a scientific product. It is an issue that is based initially on ontological (independent or not of how in research "being" is approached by consciousness) and epistemological parameters (a capacity of self-reliant or not of thinking to penetrate the data of external experience), with different priorities respectively, and subsequently closely tied to detections of logical and linguistic analysis, which more or less follow what is chosen as the original or determinative in the epistemological process. ${ }^{4}$ Our research programme is based in part on the historical element, par excellence on the systematic. It touches an issue that provoked the interest of a particular historical period and with specific cultural configurations and is approached through definite viewpoints from the conceptual-methodological material developed to set up two

Gregory of Nyssa, and the Transformation of Divine Simplicity (Oxford: Oxford University Press, 2009), passim, but essentially 143-154.

4 With reference to the distinction idealism-realism, we could generally observe as follows: According to the first interpretation, Reality dominates and embraces Consciousness. Therefore a. The cognitive relationship is registered in the real and somehow presupposes it; b. Within the cognitive relationship two terms (subject-object) come into contact, each of which belongs to a different ontological field and with their encounter is implemented a transcendence of the conscious ground (outlet-transcendence); c. The subject of knowledge is determined by its object, complies with its instructions; d. The ontological authentication logically precedes and establishes the Gnoseology - this is the theory of realism. According to the second interpretation, Consciousness dominates and embraces Reality. Therefore a. the real relationship is registered in the cognitive and emanates from it; b. On the same level, the conscious, belong the two terms (subject-object) of the cognitive relationship; with their encounter consciousness itself comes into specific contact with itself (enclosure-immanence); c. The object of knowledge is determined by its subject; this imposes its laws; $d$. The Gnoseology as critique of knowledge logically precedes and establishes the ontology-this is the theory of idealism. The use of the above considerations into the conflict of Eunomius-Basil is clearly retrospective. Both theologians do not put the use of the two terms into their argument and anyway in their time the philosophical issue in question had not been set out in strict semantic terminology. Its presuppositions had simply begun to be formulated, with the torch relayed from ancient Greek speculation. Nevertheless, we appreciate that a theoretical enterprise with ontological and epistemological parameters has to be examined also through above doublet, recapitulative of the partial approaches. Such an examination most clearly should not be divorced from related research into the field of ancient Greek philosophy, where the subject-object relationship had already been put under examination by Heraclitus (see in relation to this extracts numbered 101, 109, 194, 227, and 234). Generally the retrospective employment of a theory is legitimatized when the place in which it is implemented has exhibited, more or less, its definite exemplifications.

PERICHORESIS $11.1(2013)$ 
general theoretical structures according the so to speak genealogical evolution of philosophical through towards its ever further maturer manifestations. As to the specific object of analysis, our report will be limited to an outline text of Basil of Caesarea and our aim will be to draw it out in its full development, from one expression to the next. This is the sixth chapter of the first book from the treatise Against Eunomius (Kata Eunomiou). ${ }^{5}$ We will be concerned therefore with the process through which the Cappadocian theologian develops his syllogistic reasoning and at the same whether we have the legitimate grounds for approaches and categorizing based on the above theoretical doublet. In other words, we go along with the text in the framework of a quasi-genetic development, within which will be examined how the conceptual patterns gradually acquire their precise definitions and theoretical integrations. In the concluding parts of our study we shall try to express some concerns, which will extend the reasoning which Basil develops and which in their general context will be referred to the encounter between philosophy-theology in his work and to that of his opponent in the sense of the demarcation of the relationships-differences. Besides there is reference to an issue which has concerned Christian thought at all is historical stages, as much in the East as in the West. ${ }^{6}$ And of course the treatment of such an encounter will be connected by extension with whether, albeit in the occasions of a text limited in extent it is legitimate to talk about Christian philosophy as a general and up to a point self-reliant historical and systematic theoretical branch, or whether we should keep simply to the fact that Christianity proceeds in timely use of philosophical stocks, to establish even more firmly its theoretical concerns.

\section{Bewilderment as Occasion for Defining}

Initially, Basil the Great poses the question about the definition of conceptualization (epinoia $)^{7}$ in itself-that is to say, apart from the processes through which it formulated-and adds, choosing a borrowed speculation of superficial operation, perhaps it is a simple sound which the tongue arouses in each of its particular momentary expressions. Indirectly he will mean that it is a question of a vocal expression of such an order that it will be independent of what meaning conventionally it could reproduce and of whether there precedes as presupposition about its formulation a thorough intellectual elaboration. Practicing a critique of his resultant borrowed 
questions-which more particularly spring from the same grounds as-those of Eunomius-he points out that such an interpretation would either more in the realm of irrationality (distortion or misleading of the epistemological process) or in superficial analyses of human speech, or would constitute babble. ${ }^{8}$ We would note that this is a question of a location of the argument in extreme idealism-appearing here as unexamined, as simplistic and without elementary refining-which nevertheless is rejected from every viewpoint as objectively absurd, as not applicable to any circumstance and obviously as not suitable for authentic socio-dialectical encounters between people. Indeed, apart from other things, it reduces the property of idealism, critical self-consciousness and conceptual self-formation of thinking and by extension underestimates in the epistemological what is included in human intellectual centers. It needs stressing that at the commencement of the reasoning we refer to idealism in the sense of the isolation of the word as sound of reality, what follows will highlight new possibilities for categorical interposition.

The second interpretation which follows immediately is more moderate and seems to be supplied from data of human-and by extension social—reality and to be more tested with regard to the criteria for its foundation with which it comes into the forefront of the argument. It is recognized that conceptualization (epinoia) must have a special, albeit minimal, function in the context of the activities of human consciousness. We could add here that it arises as a consequence of an epistemological process or at least constitutes an occasion for leading to an, obviously conscious, choice about something analogous. For the present anyway our addition constitutes a hypothesis. Nevertheless it is stressed-again with Eunomius as the occasionthat its reference can be directed to a non-existent reality or to a false representation, in the imaginative way, for example, in which stories are formulated. ${ }^{9}$ That is

Contra Eunomius 1, 6, 1-5: "Auto de touto ei pote estin hē epinoia, hēdeōs an auton erōtēsaimi; ar'ouden pantapasi sēmainei to onoma touto, kai psophos allōs esti dia tēs glōttēs ekpiptōn? Alla to toiouton ouchi epinoia, paranoia d'an mallon kai phlyaria prosagoreuoito", ["So I am glad to raise the question: what in the world is a conceptualization? Does this term signify absolutely nothing, being merely a noise escaping from the tongue? But such a thing is not called conceptualization, but rather craziness and babbling!” Mark DelCogliano and Andrew Radde-Gallwitz, St. Basil of Caesarea, 96-97]. We refer you indicatively to G. Martzelos, Ousiai kai energeiai tou Theou kata ton Megan Basileion [Essences and Actions of God according to Basil the Great] (Thessaloniki: Pournaras Editions, 1993), 150. On his part G. D. Panagopoulos, $\bar{E}$ stōikē philosophia stē theologia tou Megalou Basileiou [Stoic Philosophy in the Theology of Basil the Great] (Thessaloniki: Herodotos Editions, 2006), 160, approaches the issue of names' origin with theoretical classifications. It should be noted that names given by God, as authentic and as corresponding to things, open channels towards realism.

9 Cfr. Contra Eunomius 1, 6, 5-11: "Ei de synchōroiē sēmainein men ti tēn epinoian, pseudes de touto pantelōs kai anyparkton, hōs en tais mythopoioiais kentaurōn dē tinōn anaplasmous kai chimairas, pōs to sēmainomnenon pseudos tō psophō tēs glōttēs synaphanizetai, tēs men phōnēs pantōs eis aera procheomenēs, tōn pseudōn noēmatōn enapomeinontōn tē dianoia?" ["Now what if Eunomius were to concede that a conceptualization does in fact signify something, but something completely false and not-existent, like the fictional centaurs and Chimera that appear 
to say describing a compound of actions, relationships and functions, which is constructed for special reasons of a mainly emotional order by people, or in a world where it secures for them, albeit superficially, psychological balance. That is to say, in a reality outside current ascertainable and classifiable experiences, which has not even an elemental historical jumping off point or one of clearly scientific description. It should be further noted that texts of such a kind remain in human consciousness or in the subconscious due to the operation which they fulfill in questions of existential and indeed explicitly non-rationalised functioning. They refer in any case in an epistemological atmosphere to idealism in so far as they come from a different route to serve their themes and imaginary projections.

Nevertheless the reference here to the false is not only made for reasons of description or analysis but also in order that in a firmer manner may be formulated the subversive argumentation which has already been set in motion by Basil and

in the mythologies? If this were the case, how does the falsehood, once it is spoken, dissolve together with the noise of the tongue, seeing that the false concepts remain in the mind after the voice is entirely dissipated into the air?", Mark DelCogliano, and Andrew Radde-Gallwitz, St. Basil of Caesarea, 97]. M. S. Troiano, commenting on the above section of Basil observes: "Anche quando l'epinoia sta a significare qualcosa di falso ed inesistente, come nelle favole I centauri e la chimera, pur sempre i falsi concetti rimangono nella mente, e non può essere che il falso che è espresso mediante la parola si disolva col suono della voce allorché questa si dissolve nell'aria. Infatti l'anima ritiene nella memoria le finzioni del tutto false e vuote, frutto della fantasia del sonno e dei folli moti della mente, e allorché le esprime con la voce, insieme con la parola non é che svaniscano anche le imagini", ["I Cappadoci e la questione dell'origine dei nomi nella polemica contro Eunomio", Vetera Christianorum 17 (1980): 313-346, at 323]. Paul Kalligas, progressing towards an historical retrospection of the question, sets out as follows the views of Eunomius about names: "Eunomius, who served for a short period as bishop of Cyzicus, was a spokesman for the most extreme branch of Arianism, the so-called Anomeans, who denied the existence even of any similarity between the substances of the Father and the Son. As a disciple of Aetius, a personage whose extraordinary erudition had impressed even Julian the Apostate. Eunomius acquired a considerable philosophical training, which he applied to the construction of an impressive theological system resting on Neoplatonic foundations. In the course of buttressing an argument to the effect that the term "unborn" (agennetos) constitutes a name of God expressive and the correspondence "in accordance with truth" (kat' alètheian) of specific names to the nature of the objects they designate, as opposed to the association "in accordance with human conception" (kat' epinoian anthrōpinēn) of all other names to things, towards which these have no semantic or other objective relation, so that no sooner are they pronounced than they vanish. This theory has its roots, in the "teaching of Euthyphro" as presented by Socrates in Plato's Cratylus, and which was widely influential among the Neopythagoreans and certain Neoplatonists. However much it served to support his views on the selective manifestation of divine providence in the universe through specific "seminal words" (spermatikoi logoi) which were implanted in the souls of Adam and Eve, it also led Eunomius to the blanket denial of the semantic function of all other common names, since for him the "conception" (epinoia) they evoke adds up to no more than subjective invention or simple phantasy. For to the nature of things correspond only those names which were established "connately" (prosphyoss) and appropriately (oikeiōs) by God himself during their creation, and this nature may become known to man only through some kind of apocalyptic revelation (Paul Kalligas, "Basil of Caesarea on the Semantics of Proper Names", Byzantine Philosophy and its Ancient Sources, ed. by Katerina Ierodiakonou (Oxford: Oxford University Press, 2004), 40-41.

PERICHORESIS $11.1(2013)$ 
has as much content of an epistemological as of an ethical order. So in the case of the epistemological correlations which Eunomius is presented as promoting, it is stressed by the Cappadocian that we do not have the fundamental reasons for assuming that, when sound ceases to exist, falsehood also is terminated in a mechanical automatism. On the other hand, a question is posed which has its occasion in logical contradictions which occur within the suggestions of Eunomius. In particular, how would it be possible for the only things remaining in the mind to be false ideas, in the form we would say of an impression, so to speak, which would maintain a presence for a certain interval indelible but superficial, and with national and why not also practical—extensions? How is such persistence and its explicit determination to be explained at the point where the argument about instantaneousness is formulated by the heresiarch? That is to say, Basil draws his critical ideas from data which are verifiable from the way in which the human inner world by assumption functions and in the way in Eunomius develops them. It is necessary is a to stress that, apart from the grasp of criticism, a distinction emerges and at the same time a connection between the signified falsehood and the signifying falsehoods which particularly here has its basis in the instantaneousness of the expression of speech as a projection of the human intellect and not in a systematically elaborated analysis with reference to whether speech arises from an established foundation. That is to say, insofar as Eunomius accepts instantaneousness, he should not proceed to categorical-and indeed un-condescending-definitions. At any rate in the thinking in which the question is projected, speculation emerges about whether a false-as well, of course, as what is a true-sense has presuppositions for existing for a short or extended space of time or only instantaneously. And in the position in question the Cappadocian theologian exercises a critique of pragmatic structure, stressing that, when a falsehood remains in passing of its verbal expression it will itself be lost as regards its semantic appearances and semasiological extensions, or obviously-we would add-will exclude certain elaborations in the field of ideological formulations and stools. ${ }^{10}$ Clearly also he will mean that memory does not constitute a mechanistic and instinctive process, but that from experiences it formulates representations, plasmōn, è en tais kath' hypnon phantasiais. è allōs en tois mataiois tou nou kinēmasin hē psychē plērōtheisa, parakataschē tē mnēmē, eita dia tēs phōnēs exangeilai proelētai, homou tō proenechthenti logō synēphanisthē kai ta phantasmata", ["For whenever the soul has become filled with utterly false and vacuous fictions, either the impressions received during sleep or simply the idle movements of the mind, and the soul retains these fictions in its memory but then willingly chooses to make them known with the voice, it is not the case that these mental impressions dissolve together with the words that expressed them", Mark DelCogliano, Andrew Radde-Gallwitz, St. Basil of Caesarea, 97]. Imaginary ideas, of course, belong to the category of a whimsical and certainly unsophisticated idealism, but do not confirm the ability of consciousness to selffashion in a critical and reflective manner. They transfer it to a field where cohesive reasoning and objective enterprise are explicitly absent and, of course, the complete issue of a priori is not set for elaboration.

PERICHORESIS $11.1(2013)$ 
which will be set, at a more complex stage of their engagement, in an intellectual elaboration. The conjectural endeavor at application which Basil brings, in prospect of a plausible expediency, we would say of an ethical order, is that it would be worth us formatting falsehoods, if their content was guided to loss in common with those words which as active stimulants express them. The expediency, of course, depends on the fact that the falsehoods would not have an established presence and then would not have a negative effect on human consciousness, when also the circumstances for the actions and for the communications were avoided.

Nevertheless, from the context it follows that Eunomious would not accept the thinking in question, if he remained constant, upholding an instantaneous simplistic realism of sound and denouncing for idealism the creators of concepts insofar as the fabricated names ${ }^{11}$ have no presence in the succession. That is to say, Basil could accept that in the false of an unethical action of whatever kind as alien from the rules of correct living, false speeds is preferable. And in any case Basil considers this position as abnormal and naive, estimating obviously that Eunomius is obliged to explain what is meant by conceptualization referring in some way to certain unspecific matters and perhaps we would add, only to their notional-and of course according to his familiar thinking counterfeit-elaboration. That is, on what data is his argumentation based, so as to scorn entirely human epistemological production as a whole? The accusation on his part about extreme autonomy of thinking accompanied by the internally contradictory endeavor concerning his complete self-contradiction does not constitute a theoretical labor which could be put into strict scientific processing, because the authentication at least would be absent. Basil cannot accept that the signifiers and signified in the formulation of a concert are set on the fridge of epistemological and nominal impressions, because finally the word expressed on each occasion would be without sense, not only practical but also theoretical. According to all we have mentioned, we conclude for the present with the following two assessments: a. the extreme extension of epistemological disdain for conceptualizations would be the complete downgrading of a human being as creative intellectual being, a position which is out of tune with theology concerning the creation of mankind "in the image" (kat' eikona) of God and of course in his ability "in the likeness" (kath' omoiōsin); b. external reality undoubtedly also should be understood as an autonomous area, which must be allotted the necessary respect by people so that they are not led to an intellectual autoerotism which will bring only their self-authentications. ${ }^{12}$ Nevertheless, the respect in question will not be founded on the self-annulment of the thinking subject.

11 On both Basilius' and Eunomius' theory on names and naming, see DelCogliano, Basil of Caesarea's Anti-Eunomian Theory of Names, 38-48 and 189-260, respectively.

12 See Vl. Lossky, The Vision of God, trans. by John Meyendorff (London: The Faith Press, 1973), 62, where the author presents as subsequently the deviations of Eunomius in connection with Christian epistemological positions. Therefore it is a question of an epistemology which does not belong either to the field of ability. Since it introduces a skeptical misgiving and goes far and 


\section{The Relationship between Thinking and Being}

Proceeding to an analytical presentation of the term "conceptualization" and as regards the elaborations which he presupposes for obtaining its full content, the Cappadocian Father mentions that, in the common approach to the question, when the mind grasps an object in a general way, at first it considers it as simple and isolated from the remainder. We should add in a kind of existential autonomy and without functional and communicative projections, or without its active or suggestive incorporation in a more general context of presences, functions and connections. Subsequently, however, the mind intervenes with conceptualization through which procedural applications the object is shown to have variety and is distinguished with its theoretical interventions in its many-to some extent on occasion-parts. Namely its formative specifications are located, obviously of course-albeit a posteriori-according to their organic co-existence and not in isolation from each other. As an example there is introduced the body, for which it is stressed that the second level of its approach it is perceived to be a compound of color, shape, mass and size and of whatever qualities of its own category. ${ }^{13}$ It is a question indeed of essential features we would characterize-which if absent, the same body would not be able to

away beyond the limitations of agnosticism. And then the question also would be posed as to what extent the development of knowledge was attainable.

13 Cfr. Contra Eunomius 1, 6, 21-29: "Horōmen toinyn, hoti en men tē koinē chrēsei, ta tais athroais epibolais tou nou hapla dokountai einai kai monacha, tais de kata lepton exetasesi pokila phainomena, kai polla tauta tō nō diairoumena, epinoia monē diaireta legetai. Hoion, to sōma haploun men einai phēsin hē prōtē enteuxis, poikilon de ho logos epiōn deiknysi, tē epinoia auto eis ta ex hōn synkeitai dialyōn, kai chrōma, kai schēma, kai antitypian, kai megethos kai ta loipa", ["Therefore let us first look at common usage: whatever seems simple and singular upon a general survey by the mind, but which appears complex and plural upon detailed scrutiny and thereby is divided by the mond - this sort of thing is said to be divided through conceptualization alone. For example, at first glance the body may seem to be simple, but when reasoning is used it reveals that the body is complex, dissolving it through conceptualization into the thing out of which it is constituted: color, shape, solidity, size, and so forth", Mark DelCogliano, Andrew Radde-Gallwitz, St. Basil of Caesarea, 97-98]. Formulating a deductive judgement, M. S. Troiano observes: "E dunque evidente che Basilio qui identifica l'epinoia con la facoltà razionale umana, con la capacità di analisi" (I Cappadoci e la questione, 316). It is interesting that there becomes a distinction-but also a connection- between the appearance as expressive of the functioning of the characteristics and the demonstration with regard to the degree of completeness and objectivity of the epistemological article. The question has particularly preoccupied medieval and modern philosophical thinking. The discussion in question in the context of Eastern Christianity was set up after a short space of time by Gregory of Nyssa (Pōs tria prosōpa legontes en tē theotêti ou phamen treis theous pros tous Hellēnas apo tōn koinōn ennoiōn, Ad Graecos ex communibus notionibus, P. G. 45, 175-186) and subsequently by Leontius of Byzantium (Logos kata Nestoriou kai Eutychous, Contra Nestorianos et Eutychianos, P. G. 86/1, 1273a-1308a) and by Arethas of Caesarea (Scholia eis tēn Porphyriou Eisagōgèn, J. Vrin, Paris 1994, 43, 5-46, 21 and 50, 20-52-17). For the purpose of our study, we refer you to a quotation of the above treatise referred to epinoia: "Isteon de hōs diapherei psilē epinoia haplōs epinoias. HĒ men gar psilē epinoia tōn mē ontōn esti tēs hēmeteras dianoias anatypōsis, hoion tragelaphos; touto gar ouk estin ei mē hē dianoia touto anatypōsētai hē hēmetera. Haplōs de epinoia esti to chōrizein tō logō ta tē physei hēnōmena, hoion,

PERICHORESIS 11.1 (2013) 
exist or would have a deficiency or defective presence. They are determinative for its configuration or at least for its functioning. They could even be regarded as compositional preconditions, or more modestly that they emerge simultaneously in common with the body when the essence and its properties are found in a state of equivalence and interdependence. Besides, we cannot imagine a body without size or even size apart from a real entity, an issue which was of particular concern to Aristotle, and to some extant also Plato. It would not be inappropriate indeed if we claimed that the distinction, for example, between the body and its size is only for reasons which serve theoretical analysis. It is also to be noted that both of them increase and decrease simultaneously in common, unless we have indicated that these particular changes take place in the body size or in the body according to its size.

At the end of his descriptive accounts, the Cappadocian theologian stresses that subjects are considered from recurring usage to be even in certain cases non-existent and here he classifies these objects, which do not have ontologically viewed in fact not only archetypal function but also ascertainable physical presence. It is a question of formations of intangible realistic basis which have been depicted by fabulists and painters out of the fecundating unfolding of their imagination and with the aim of impressing the above category will be mistaken for a reality of another value—constructional—which nevertheless will fall short entirely as regards objective genuineness, insofar as it is nothing but the product of a technical faculty, a talent which shows its shaping with the employment of the instrumental means necessary on the occasion. ${ }^{14}$ And indeed it is a question of means which usually or always are drawn from nature, without being however more existent or lining realities, that is to say without there being found the natural properties in question as active condition. What is most probable then is that Basil considers them objects which, by reason of their constructed texture, are not subject to absolute epistemological approach and are not fully describable in strict refined conceptual categories, when, there are chosen for their expression not directly declaratory but allegorical

tēs physeōs hama dēmiourgousēs chrōma kai onkon, hēmeis tō logō chōrizomen auta kai tē epinoia ap' allēlōn kai to men hypo to poion, to de hypo to poson" (9.21-10.2).

14 Cfr. Contra Eunomius 1, 6, 29-33: "Palin ta anypostata men pantelōs, kata de anazōgraphēsan tina tēs ennoias kai phantasian monon anatypoumena hōs hosa hoi mythopoioi kai zōgraphoi pros tēn tōn entynchanontōn ekplēxin terateuontai kat' epinoian, kai tauta theōrēta hypo tēs synētheias legetai" ["Another example would be completely non-existent things envisioned only by a sort of conceptual portrait-painting and imagination, such as is marvelously done by myth-writers and painters to astound their audience: according to customary usage of language, such things are said to be considered by way of conceptualization", Mark DelCogliano, Andrew Radde-Gallwitz, St. Basil of Caesarea, 98]. With ease in this reasoning we could classify everything included in the category of the aesthetically or artistically significant, which is not subject to the determinism of natural development or of mechanistically recurrent phenomena, but constitutes a reality which arises as a quasi-dependence on nature. And the realistic criterion recedes here perceptibly, insofar as the above acquire their existence through a creative perfection of a subjective character. See indicatively, M. C. Beardsley, Aesthetics (Indianapolis: Hackett, 1958).

PERICHORESIS $11.1(2013)$ 
ways of expression or descriptive ones through an artistic —of an aesthetic kindterminology. That is to say, there come to the fore imaginary reconstructions of human inventiveness that do not belong to the same outlook, as much as far as content is concerned, as also their form, with products of another such origin. The categories which describe the ontological order are based on objective and ascertainable presuppositions and have a broad recurring foundation in that they can be fashioned in the abstract process by more than one object of the same kind. The cognitive-logical condition in question is not easily safeguarded or can be absent, even entirely, in art, where the original, and obviously the unrepeatable predominate, and regulatory requirements have only guarantee any place for their success, where here there cannot easily be posed the question of definition except for description or narration, and indeed in terms of an inner emotion.

Advancing his critical accounts, Basil points out that Eunomius, either through ignorance (an epistemological criterion) or through deceit (a moral criterion) formulates philosophical positions with reference to the conceptualization of the nonexistent, where special structure indeed he does not explain. For example, from what presuppositions does it result? He denounces him, that is, both for methodological improprieties and for omissions of conventional logic, insofar as he does not come to make known the actual relationship which exists between being and consciousness, albeit even under the criteria of the understanding subjects. The Cappadocian theologian points out that Eunomius does not attribute any significance to the term and considers it basically a lie or denying objective meaning, so diminishing at a stroke human creative ability. Also, as a name he considers it not to lead to any significance and as a linguistic entity to acquire its existence exclusively from the moment it is pronounced, thus reintroducing also the discussion about a simplified realism of sound. ${ }^{15}$ peri tēs tōn anyparktōn epinoias monēs hēmin ephilosophēse kai oude tautēn hōs echei physeōs exēgoumenos. Ou gar sēmainein men ti tēn epinoian, pseudes de touto, phēsin alla pantelōs asēmon einai to onoma, kai en monē tē ekphōnēsei tēn hypostasin echein" ["Eunomius has made no mention of these points, either through ignorance or captiousness, and has confined the philosophical account he gave us only to the topic of the conceptualization of non-existent things-and he does not even explain this as it really is. He does not claim, you see, that a conceptualization signifies something, albeit something false, but that the term is completely meaningless and has subsistence only when it is being pronounced", Mark DelCogliano, Andrew Radde-Gallwitz, St. Basil of Caesarea, 98]. Eunomius admits objective content only in names which God Himself ascribes to matters and appoints or reveals. See Lossky, The Vision of God, 62-63, where reference is made to those names which are not products of human thought, but they do express the essence of the objects. So, people are epistemologically authentic when they rely on hetero-specifications and hetero-provisioning.

PERICHORESIS 11.1 (2013) 


\section{Definition and Function of Conceptualization (epinoia)}

Basil the Great subsequently formulates his analytical and critical positions projecting a consistent epistemological process. He mentions that conceptualization is a recollection which I detailed and constitutes an accurate description of a matter which has been understood, since previously it was engaged by the senses and evidently recorded in the memory. ${ }^{16}$ He observes that we could also attribute parallel to "recollection" (epenthymēsis) also the term "selection" (epilogismos) which people consider to be proper, to a greater degree, to everything dealt with here basing themselves mainly on the habit of reviewing. Nevertheless he points out that the term in question does not render the exact meaning of all that is mentally- cognitively engineered in human consciousness. In our estimation at any rate, it would be an appropriate term in that it imprints—or stamps with clear significativenessthe developments in a reasoning process which follows of any empirical engagements. Furthermore it would show off the epistemological activity as a process of consciousness to recall the achievements to which it had advanced and to practice criticism on their content or proceed to more nature revisions, and furthermore, of course, to proceed also to compositional judgements in a post-analytic and postdescriptive setting. ${ }^{17}$ postatōn phantasiōn, to onoma touto tēs epinoias keisthai hōste meta to prōton hēmin apo tēs aisthēseōs enginomenon noēma tēn leptoteran kai akribesteran tou noēthentos epenthymēsin, epinoian onomazesthai", "The term "conceptualization", however is far from being restricted only to vain and non-existent things-and he does not even explain this as it really is. After an initial concept has arisen for us from sense perception, the more subtle and precise reflection on what we have conceived is called conceptualization", Mark DelCogliano, Andrew Radde-Gallwitz, 98]. Here we find the predominance of empiricism but not of the simplified kind, since the question is posed of elaboration and analytical presentation of data which are engaged by the sensory organs. The predominance of the realistic model is obvious.

17 Nevertheless, the Skepticism of Basil about admitting into this thematic relationship the term "selectivity" (epilogismos) is owing to particular words which relate also to how the term has already been employed and to what he himself is aiming to show in the context of the dogmatic dispute in which he is embroiled. We will proceed to a part of the controversy which has a relation to the above theme, in spite of the fact that it does not fall within the main objectives of our study. For the non-identification, therefore, of the meaning with the selectivity, M. S. Troiano observes recalling as follows the arguments from the aresenal of the Stoics: "Dunque per Basilio l'epinoia non è propriamente l'epilogismos, cioèe, secondo la definizione che di quest'ultimo danno gli stoici non è 'la ragione commune in base alla quale concordano tutti su di una cosa"”, I Cappadoci e la questione, 316). The related distinctions of the Stoics are as follows: "Epinoia estin enapokeimenē noēsēs; noēsis de logikē phantasia" (SVF 11, 89) and "Epilogismos de ho koinos kai symphōnoumenos para pantōn logos" (SVF 269). It could be argued that epilogismos moving into mainstream use of language, or record the consensus. What arises from the preceding can be referred to the necessary scholarship which should govern the articulation of the arguments, and especially in a period when doctrinal conflicts were gone through exhaustively and through the employment of language.

PERICHORESIS 11.1 (2013) 
Subsequently, citing as an example "corn", the Cappadocian theologian mentions that we sometimes call it produce, sometimes seed and sometimes food, drawing his predicates from the way in which it happens to be approached by a person, In the variety of predicative specifications temporal development also takes part since it is not simultaneously seed and produce. That is to say, it is a question of a mode of description which is at times theoretical, at times practical or of an applicable order on condition that there is developed a multipotent dialectic between subject and object in the process of following a course of sequences. By way of explanation he mentions that the term "produce" means that a process of cultivation has been completed, the term "seed" that the beginnings of a new process of development are put into effect and the term "food" that the corn is suitable for offering possibilities of invigoration evidently, through the necessary modifications which will take place in the organism of the living being who takes it. In its final operation the corn goes beyond the limits of itself or its insertia and is rendered a stable beneficial presence. ${ }^{18}$ The multiple naming of the same object, in the sense of the systematic apportionment of its prior conditions on the basis of continual observation

Cfr. Contra Eunomius 1, 6, 44-51: "Hoion tou sitou noēma men haploun enyparchei pasi, katho phanenta gnōrizomen. En de tē akribē peri autou exetasei, theōria te pleionōn proserchetai, kai prosēgoriai diaphorai tōn noēthentōn sēmantikai. Ton gar auton siton, nyn men karpon legomen, nyn de sperma, kai palin trophēn; karpon men, hōs telos tēs parelthousēs geōrgias; sperma de, hōs archēn tēs mellousēs; trophēn de, hōs katallēlon eis prosthēkēn tō tou prospheromenou sōmati", ["For example, the concept of grain exists in everybody as something simple, by means of which we recognize grain as soon as we see it. But when we examine grain in detail we come to consider more things about it and use different designations to indicate the different things that we have conceived. For the same grain can be called one time 'fruit', at another time 'seed', and again at another time 'nourishment'. It is 'fruit' as the result of farming that has been completed, 'seed' as the beginning of farming to come, and 'nourishment' as what is suitable for the development of the body of the one who eats it", Mark DelCogliano, Andrew Radde-Gallwitz, St. Basil of Caesarea, 98]. Interest is introduced by the distinction between signifying and signified, which is based on the data of experience. Vl. Lossky (The vision of God, 64) observes in connection with the way in which Basil the Great approaches the issue under negotiation: "St Basil (330-379), in his attack on Eunomius, criticizes him first of all on the philosophical level for his theory of knowledge. He firmly rejects the distinction between essential names of objects and names invented by reflection—kat' epinoian. All names with which we designate objects are found by way of reflection, but this does not mean that this reflection is sterile, that it does not correspond to any objective reality. A body appears simple to us at first sight, but reflection progressively reveals its scope, colour, thickness, form, and still other properties. This permits us to form concepts, penetrating in this way into the complexity of objects, giving them names which express their qualities or their relations to other objects, even though we are never able to exhaust the content of a being in concepts. There always remains an unknown something, an existential depth-if this modern expression can be applied to the thought of St. Basilsomething which escapes all intellectual analysis. This means that there is not a single object which can be known as its essence, in that which makes it what it is and not something else. It must not be thought that in denying the possibility of knowing the essence of things". That is to say, the model of interpretation which Basil proposes, beyond its realistic character, is also an evolutionary subject-matter and shows the connection which perception-language have with time as a process of transition from a priori to a posteriori with regard to how Basil understands 
of its, as well as multiple meaning as significativeness of its extensions to other fields do not alter the content of its substance, but record specific measures from its various operations and its, so-to-speak, transformative interventions. An object then does not simply exist but is led in accordance with its natural specifications to various activities, to passage from particular stages for the realization of the aim for the sake of which it exists or has been set to accomplish on the basis of the special model of its presence by nature under which it is directed. Furthermore, it is constituted employable under moulded terms and in an operationally articulated frameworks and then its compatibility is apparent with other particular objects and potentially its extension through reciprocities. In a theological ambiance at any rate, like that with which Basil the Great moves, reference will be made initially at least concerning divine planning. Consequently, we would not be missing the mark if we produced a word for a teleological model, which in this way or another appears in the field of biophysical transition which can ontologically be applied also to the human level where the developmental process of an individual is understood, in terms of consciousness and actual projection of course, as passage from "in the image" to "in the likeness". And here time constitutes a fundamental factor for understanding. Also the passage in question is linked also with what is defined as self-realization of man with the characteristic of the individual, an achievement which is not met with in the rest of living nature. Consequently a fortiori the system of categories with which they will describe man as a person and the society cannot be brought to completeness. So, time offers limitless possibilities in epistemology but because of changes which rule it does not safeguard presuppositions about a definition stable and with prospect of durability.

The Cappadocian Father points out also-disputing outright the grounds of Eunomius - that the above names arise by conceptualization and are not impaired by acoustically with drawing the sound of the language. That is to say they constitute deposits which remain in individual or collective memory and evidently safeguard also essential possibilities of communication between people. Moreover, he stresses that the meanings are incised ("established" enidrytai) in the soul of the thinking

the ability of a person in epistemological acquisition of subjects in perceptible experience of entities, Paul Kalligas observes in this connection: "Basil also disapproves of Eunomius' theory concerning the names, 'in accordance with truth', asserting that knowledge of the "substance" (ousia) of things in innately impossible for human intelligence and thus indefectible through names, which, being "posterior" (hystera) to the nature of things, are incapable of revealing it, but may only approximate it through its properties" (ibidem, 41). Particular interest is introduced by the point/ thesis that, according to Basil, total epistemological acquisition of reality is not attainable on the part of a human being. Analogous views are met also in Thomas Nagel, who claims as follows: "I shall defend a form of realism according to which our grasp on the world is limited not only in respect of what we can know but also in respect of what we can conceive. In a very strong sense, the world extends beyond the reach of our minds. [...] The realism I am defending says the world may be inconceivable to our minds, and the idealism I am opposing says it could not be”, Thomas Nagel, The View from Nowhere (Oxford: Oxford University Press, 1986), 90-91.

PERICHORESIS 11.1 (2013) 
person and so he does not endeavor to set systematic foundations or to debate-at least here-the ontological or metaphysical a priori of the semantics. It is not certain then that he would adopt the platonic thinking about the theory of recollection, which is formulated in the dialogues Meno and Phaedo, or that he would introduce pre-existence of concepts in consciousness independently of empirical engagements. ${ }^{19}$ In other words we cannot claim that he is an adherent of the position that parallelisms pre-exist between unities of ideas and unities of phenomena. Furthermore indeed, he does not apply himself to the theory of Eunomius about the installation of names from God in the consciousness, so avoiding the aspect in question of persistent metaphysical realism. Also generalizing his epistemological observations, Basil mentions that an object which is subject to human approach appears to be simple-or, we would add, also united-when it is engaged only by the senses, namely on the basis of the first empirical encounter with its presence. However through its further examination it becomes understood in various ways or in various perspectives. The activation of the epistemological centres and epistemological processes produces also the analytical penetration of the enquirer into the content of the object, its theoretical formulation through concepts in part and its general list of names. ${ }^{20}$ In brief, all the above result in conceptualization, or a systematic methodical process, evidently specialized in each and every case where an object is set step by step within the horizons of human scientific research. (London: Kegan Paul, 1957).

20 Cfr. Contra Eunomius 1, 6, 51-57: “Toutōn hen hekaston tōn legomenōn kai kat' epinoian theōreitai, kai tō psophō tēs glōssēs ou synaperchetai. Alla tē psychē tou nenoēkotos enidrytai ta noēmata. Kai hapaxaplōs, panta ta tē aisthēsei gnōrima, kai hapla men einai tō hypokeimenō dokounta, poikilon de logon kata tēn theōrian epidechomena, epinoia theōrēta legetai", ["Now each one of these things mentioned is considered by way of conceptualization: each of these is not dissolved together with the noise of the tongue, but rather the concepts remain settled in the soul of the one who has conceived them. Generally speaking, all things recognized through sense-perception and which seem simple in substrate but which admit of a complex account upon further consideration are said to be considered through conceptualization". Mark DelCogliano, Andrew Radde-Gallwitz, St. Basil of Caesarea, 98]. About the content of conceptualization (epinoia), the commentator on the text of Basil in the edition of "Sources Chrétinnes" observes the following: "Dans ce texte Basile définit l'epinoia comme l'activité réflexive de l'esprit capable d'abstraction à partir des données de la perception, abstraction qui décompose et recompose rationnellement un objet en function de ses différents aspects formels. Il s'agit proprement de l'activité conceptuelle de l'esprit. Et comme l'epinoia désigne le plus souvent le résultat de cette activité, nous avons choisi de traduire par concept" (Contre Eunome, 183). The above definition records a rational, continuous and complete intellectual process which exhibits the creative character of human consciousness, which theoretically restructures the object of its study, in order to progress towards conceptions which it estimates to be necessary for it. And anyway a simple etymological analysis of the word makes it clear that conceptualization reveals what follows of the mind and its workings.

PERICHORESIS $11.1(2013)$ 


\section{Philosophical Incorporations and Extensions}

I. Extending everything we have elaborated above, we would point on the extending thought of Basilius the Great is supported on strict epistemological data with chief pivot the idealism-realism distinction and with the perspective of the formulation of a relatively modest theory which will ensure the balances and compositions or the mutual interpenetration (perichōrēsē) between them. Realism basically predominates, but it is not imposed with dogmatic moots in its elaboration. Of course, initially the Byzantine theologian puts under examination a discussion which Eunomius had promoted about the elaboration of theological speculations, which nevertheless moves in the field of the unrealistic, mainly as regards the range and institutional character of human engagements. And the utopian functioning of it in question is swing to the fact that it becomes the reason for a potential and of automatic type, pragmatism of sound independently concept which expresses or the deeper conceptual which provoke. It is a question of an extreme sensory realism, which however, because of the automatism with which it arises and is discontinued or even abolished, is beyond the limits of the objective for the requisite human data. In something indeed the Cappadocian intends to show that in formulating the estimation that the reality of a word-as well as of its meaning and implications-lasts only for the time in which it is expressed and engaged auditorily, it must necessarily, be set in the field of instinctive enunciation and engagement. However in this way a person would be degraded to a being that functions mechanically, insofar as his/ her abilities are extremely depreciated for productive thinking. Indisputably there has come to the fore a discussion without a certifiable basis, because it is not taken into account that what is heard forms representations in the human brain, albeit vague and initially not notionally defined. What potentially occurs in the rest of the animal kingdom in terms of instinctive reactions we should not necessarily transfer to the human being, who in contrast to the rest of the animals is not approached with the forms "race-species" (genos-eidē) or "one-many" (hen-polla). It is a question of forms which mainly function in a predisterentiated deterministic way and with such conventional repetitiveness that in the case we are investigating formulate a rudimentary code of reactions as quasi-automated and unelaborated conceptions.

Nevertheless, on the real data which are also finally chosen for the formulation of conclusions, Basil the Great comes to use a compromise epistemological solution, which does not violate realism, while on the other hand it rises in the scale of the scientific values and certain principles of idealism. He follows the typical procedure which was supported by Plato ${ }^{21}$ and Aristotle, ${ }^{22}$ in accordance with which empirical data stimulate the sensory centered of a person and through appropriate procedures undergo subsequently a semantic analysis with refined categorical incorporations. It is a question of a systematic course, which converts a material object from a simple presence into a theoretical construct-or approaches it with one already

21 Plato, Theaetetus, 122 a-165 c.

22 Cf. Aristotle, De anima, 408b-417b. Analytica Posteriora, II, 19, 99 $\beta-110 \alpha$.

PERICHORESIS $11.1(2013)$ 
formed-and subsequently to its naming. The entire ascending epistemological course which is chosen exploits the data which constitute human perspective infrastructure, with the result that the discussion is not diverted into non-objective circumstances and does not impose uncritical hierarchies between the data of reality and the experiences which arise from their content. Of particular importance is the fact that there is handled directly or indirectly the formulation of the representation (parastasis) or of the so-to-speak adding alteration which is undergone by consciousness, which is not only a formulation of stimulations but also a driving force for categorisations, which constitute the epistemological process as composite design and as scientific result through deductions and not as mechanistically simplistic or instinctive conversion to the object of reference. ${ }^{23}$ Therefore the product which arises is nothing other than the transition from the vaguer and confused to clearer and defined figurative compositions, as passage from the engagement with the simple presence to its comprehension as fabricated body, that is an existence with properties as much proper as functionally outstanding. The object under investigation certainly is the same, but the development is observed only in the investigating subject through the expansion of the analytical advances, with the result that they render them finally post-analytic. Thus, it is set off as a more general design for the superficial approach to be surpassed, to secure reliable and objective reasoning procedures, which as specialized and rationally articulated come to formulate a firm scientific product, to which, apart from the fact that the theological atmosphere is predominant, the contribution of the human is crucial and continually renewable. ${ }^{24}$

Indeed the genuine objective source of the product in question comes to the fore rendered further and further knowable even through its developments, which can be viewed also as successively articulated in depth of historical time. That is to say, the emergence into "being" as a quasi-subsisting fullness is unfolded developmentally as the realization of a seminal condition. The understanding follows a "being" Caesaria, observes: "On the contrary, to the intellectualized and impoverished world of Eunomius he opposed an extremely rich world, a world inexhaustible for thought, to the passive revelation of essences impressed on the soul by God he opposed the activity of human knowledge and at the same time its objective character. We do perceive the actual properties of objects, even if the names by which we designate things do not really express what they are in essence". It is of special interest that we meet analogous views even in Nagel, The View from Nowhere, 91, who points out: "But the world is in a strong sense independent of our possible representations, and may well extend beyond them. This has implications both for what objectivity achieves when it is successful and for the possible limits of what it can achieve. Its aim and role rationale is to increase our grasp of reality, but this makes no sense unless the idea of reality is not merely the idea of what can be grasped by those methods. In other words, I want to resist the natural tendency to identify the idea of the world as it really is with the idea of what can be revealed, at the limit, by an indefinite increase in objectivity of standpoint". The above comparisons, at any rate in their totality, do not arise from agnosticism or extreme skepticism but from awareness of human limitations.

PERICHORESIS $11.1(2013)$ 
which crosses from "becoming". Thus, the fact that the connections of the thoughts are established progressively corresponding with connections of phenomena means that not only the ontological state but also the epistemological is not originally definitive. Consequently we would repeat that the system of epistemological categories-and therefore of definitions-is not satiated but follows the dynamic development of the matters. Therefore, it is renewable, not easily classifiable and open to addition and subtraction. ${ }^{25}$ There comes to the fore then a reality with the elements of transience and perhaps of the unforeseen, a condition nevertheless which is consolidated also by the fact that, as we have already mentioned, the model is theological and therefore directed by divine will-foresight, which is not easily defined by human consciousness. The negativity constitutes a condition which sets for investigators explicit limitations, which indeed they are not aware of, if in the position on the completion of the course of investigation to surpass it, even if having understood the teleology, which is predominant and governs indeed also the people themselves. Nevertheless the thinking subject sets down the competences and show that they are not satisfied with a superficial empirical realism, which in this way or another is closely interwoven with instinctive reactions or at least with rudimentary sensory and intellectual. Besides, according to the dogmatic teaching of Christianity, people are called upon to activate further and further the intellectual depth which they have been granted by God on the basis of their creating in "His image" and by extension the teleology which governs it. ${ }^{26}$

II. The methodological course with which Basil the Great forms the reasoning is supported in an attempt at transition from simplistic observations to more composite in order to conclude through the formulation of investigative queries-therefore of renewable projections of thought-in strictly scientific, such that they not only reveal in a realistic way intellectual abilities but also illuminate the data of experience. That is, he applies to some extent the Aristotelian thinking about upgrades in the fulfillment of the investigative undertaking with regard to an issue from the more superficial, approachable and knowable to the more expanded from the aspect of depth of specialized examinations. ${ }^{27}$ The question which would be put would refer to why the Cappadocian theologian persists exhaustively in a process of such structure at the moment when the readers to whom it is directed have to an

Here we could refer to the more general gnoseological positions of Christianity in accordance with which scientific "capture" of reality is carried out gradually, apart from others, also from the fact that the divine design is not revealed completely to human beings and obviously is not realized once for all and from the outset. In relation to the question of negativity, we resort again for comparative co-examinations to Nagel, The View from Nowhere, 91 who points out: "But human objectivity may fail to exhaust reality for another reason: there may be aspects of reality beyond its reach because they are altogether beyond our capacity to form conceptions of the world".

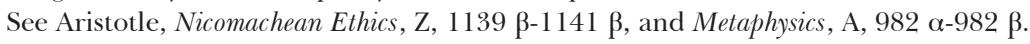

PERICHORESIS $11.1(2013)$ 
advanced extent knowledge of theological questions or have an inkling of their contents, while also even sufficient philosophical education or a t least the ability to understand that a concept cannot be exhausted in a sound. Moreover, tin this way or otherwise it would be understood that the question is scientific and that it is connected with special tasks of the brain, which must be taken into account for each theoretical formulation. The most probable answer is that Basil the Great intends to show, with as much emphasis as he deems necessary, to his readers the greatness of the improprieties of Eunomius would fall. Consequently, with every confidence we would claim that he resorts even to an irony of a special type, but with a cohesive procedure, which aims to deter readers from misapprehensions which a supple, of so-to-speak sophistical type, reasoning crafting can bring about and which obviously will lead to a series of further, improprieties, crucial for the dogmatic doctrine of the Church. And of course he will have defined as his duty to safeguard in the contrast of his pastoral functions from deviations also those of the faithful who did not have clear knowledge of theological questions and who usually would belong, in common with the educated, to his regular audience as prelate.

The employment of the epistemological undertakings which consequently takes place is explicit for the Byzantine theologian's philosophical knowledge, because it shows with each manifestation that is most clearly belongs to the horizon of his scientific equipment, speculation which has been developed in ancient Greek philosophy with regard to the relationship of empiricism, rationalism ${ }^{28}$ and consequently of realism-idealism. Correspondingly, he shows that he holds the question in conception with the relationship which exists between essence and the contingent ${ }^{29}$ and presupposes what precedence is accorded to the process of formulation of the cognitive product. According to the first version, the senses take precedence, whereas, according to the second, precedence belongs to the inner composition and elaboration of them, which through the moderate solution which it would propose would support the process for the composition, and consequently of course its naming, of the cognitive product in the beginning in the stimulations which the senses receive and consequently in the intellectual elaboration of them and their categorical classification. As we have established, Basil is indeed toward the moderate solution and so avoids the extreme cognitive constraints. It is a question of the discussion with relation to whether essence constitutes the ontological basis of development of properties or if the combination of properties contributes to the formation of essence. If the second case is valid, essence is led to its abolition as initial authentic reality. Of course, in the context if a moderate nominalism the position can be maintained that such an essence is developed in common and simultaneously with its properties, in the perspective of a so-to speak self-formulation. Nevertheless, in the last case most clearly also it cannot become a discussion about ontological grounding of the "whole" but only about their gnoseological-logical impression. In the theology of the Cappadocians, the "whole" as much as the partial constitute objective realities and between them are related chiefly through form: "one-many", in which also a central position is taken by matter, for which is rejected the interpretation about its passivity, or even about a neutral function of it. It is a question of the discussion with relation to whether essence constitutes the ontological basis of development of properties or if the combination of properties contributes to the formation of essence. If the second case is valid, essence is led to its abolition as initial authentic reality. Of 
indeed in the differentiation of primary and secondary contingencies. ${ }^{30}$ Here it comes about with reference to distinctions which define compulsory priorities and dependences, the upset of which will bring confusion to consciousness as regards ontological data in their specialized articulation in the field of Cosmology. Generalizing we would note that the Cappadocian theologian has clear sense of the relationship which exists between ontology and gnoseology even of contingencies or consequences which must develop between them in order to avoid as much the conquest of "being" by an unbridled interventionist function of "consciousness" as well as submissive functioning or even annulment of the latter. The only thing that we could claim is that potentially he undertakes to locate even their parallels, because most clearly also he does not depreciate, thinking in a Christian way, human intellectual activity. The epistemological ability-competency of the human being cannot be debarred from creating notional ramifications on the basis of the data which by Divine Revelation grants through natural phenomena. ${ }^{31}$ In our estimation, Basil's final product at only rate will be not only to lay the bases for forming a system of categories which will be simultaneously both ontological and gnoseological but also "reconcile" the subject with the object to which it referred. In other words, for the connection and the inner variety of consciousness to be able to radiate its projections to the equivalent situations of external reality. ${ }^{32}$ Besides, the recon-

course, in the context if a moderate nominalism the position can be maintained that such an essence is developed in common and simultaneously with its properties, in the perspective of a so-to speak self-formulation. Nevertheless, in the last case most clearly also it cannot become a discussion about ontological grounding of the "whole" but only about their gnoseological-logical impression. In the theology of the Cappadocians, the "whole" as much as the partial constitute objective realities and between them are related chiefly through form: "one-many", in which also a central position is taken by matter, for which is rejected the interpretation about its passivity, or even about a neutral function of it.

30 It is a question of the distinction between the characteristics which are considered to be innate in the essence of an object and those which result subsequently and which basically must be compatible with the former and perhaps complementary to their content. Indeed the primary can be taken as necessary for the conversion into being of an entity. With the secondary basically there is discussion about how an essence is influenced by external conditions and activates, develops, or enriches the existent, in the broad sense of the term, data which it possesses from its natural specifications. For example, corn could exist even without its functional characteristic as foodstuff, while its existence would be impossible if not activated internally or, so to speak, by a vital-kinetic process to transform the seed into produce. On a systematic basis the question was posed for the first time by Aristotle (see Aristotle's Topics, D and E, and Metaphysics E).

31 See J.-Claude Piguet and Gabriel-Ph. Widmer, Le renversement sémantique. Dialogue d'un théologien et d'un philosophe (Paris: Revue de théologie et de philosophie 1991): "Un problème est le suivants y a-t-il des niveaux dans l'expérience, auxquels correspondraient des niveaux dans les langages qui expriment, transcrivent on traduisent ces expériences?" (119) and "Théologiens et philosophes entendent parler sur la Réalité; ils doivent donc chercher le type de Langage qui soit leur et qui puisse être mis en correspondance avec le Réalité. Or entre la Réalité et le Langage qui entend parler sur elle, la Pensée a toujours servi de médiation assurée, de façon traditionnelle, par les concepts" (133). For the more systematic authentication of divine essence by divine activities.

PERICHORESIS $11.1(2013)$ 
ciliation in question constitutes also one of the fundamental aims of Christian Theology and reflects its stance that a human being should not be weaned by the natural environment, since in common they constitute products of the demonstration of divine activities. And correspondingly with their content, the Cappadocian Fathers formed a systematic theory, which occupied Eastern Christendom at East until even the age of Gregory Palamas, on each and every occasion with timely anthropological-eschatological-soteriological extensions.

III. The final question which awaits his syllogistic analyses must necessarily, in view of the special orientation of the text which we examined, refer to the degree of knowledge of the views of ancient Greek philosophy concerning language held by the protagonists of the controversy which preoccupied the early Byzantine period and, more specifically, what was the regulatory position of the Platonic dialogue Cratylus on the positions which they support. In our estimation, summarily, there is a strong possibility that Eunomius, as much as Basil, is aware of the related speculation which was unfolded in this particular dialogue by Plato. Initially Eunomius, in accordance with the idiosyncratic persistent realism which governs him, would accept the natural inherence of names also in objects, insofar God is the person who creates them as particular objects and so names them. Consequently, for human nomenclature to be legitimized, it must uncover what has been revealed by God. Basically, Eunomius would not have objections to accepting that penetrating into his inner being a human being discovers what God has supplied in objects. At this point it is necessary to mention that in the first six chapters of the platonic dialogue Socrates observes that objects as far as their genuineness is concerned have their own familiar essence, their own characteristics and are subject to the changes which appertain to their ontological structure. Therefore human beings are obliged to name objects exactly as they are and not at will. Consequently, the correctness of words depends on whether they accurately render the ontological particularity of objects. Indeed in chapter 43 Socrates claims that true knowledge springs from the objects themselves and not from their names, persisting thus in the objective-or realistic a priori-criterion of truth. It is obvious-and this is made known in the dialogue-that Plato excludes the standard (and in accordance with the peculiar social, historical and cultural conventions) use of names. In conformity with the above, we would easily claim that Basil would agree with the positions which Socrates formulates since, as we have ascertained, he considers that a person renders names through a consistent surveillance of the essence and functions of objects. Nevertheless, he does not pose here as a case for examination whether names physically inhere in objects. He persists in the consistent correspondence of thinking subject and thought object as of signifier-signified, avoiding, of course, dealing systematically also with the matter of outlets concerning interpretations, thus maintaining to some degree also the principles of negativity in the field of Cosmology. Accordingly, he would heartily agree with the following indication by Th. Nagel: 
"There is also the question of whether we can think of these objects 'as they genuinely are' or merely 'as they appear to us'. But what exists on what happens does not necessarily coincide with what is a possible object of our thought" (The View of Nowhere, 163). Of course the knowledge which the two theologians possess about the linguistic detections in ancient Greek philosophy is not exhausted in Plato. Analogous tendencies-and indeed particularly systematic — are encountered also in Aristotle's On Interpretation and in Stoic and Alexandrian grammarians and in Plotinus Enneads, VI.2. It is a matter for discussions which will preoccupy especially the pervading intellectual atmosphere of the later Hellenistic period. Besides, it should not escape our notice that the argumentation of Basil concerning conceptualization and more general speculations about language was expanded by his brother, Gregory of Nyssa, chiefly in his treatise, "Against Eunomius", a key element for research which took place in the early Byzantine period. Our concise reference to the Cratylus aimed simply to show that the Basil-Eunomius dispute can be reduced to such a historical depth which will ensure its-in the standard of the tangible-objective, investigative and interpretative approach. Indeed in the context of a new research discussion it should be examined how in what we investigated can be shown also the nominalism-realism dispute, mainly as regards the distinction or synonymity between abstract and particular terms. Nevertheless we must wait for definite for their elucidations in the distinction concerning the natural or imposed pressure of names. We refer relatively to Troiano, who provides an historical and systematic promotion of the issue in both the Neoplatonic and the Christian thought and, among others, she notes the following abouth the issue we dealt with: "Viceversa Basilio prima e Gregorio di Nissa poi affermano coerentemente la tesi dell'origine umana dei nomi, che sono dunque thesei. Circa il rapporto tra nome ed oggeto significato essì fenno loro la tesi che vuole in nomi in relazione con la natura delle cose, dunque physei $[. .$.$] . Ammonio arriva poi alla conclusione che il secondo dei significati$ del physei si accorda col secondo dei significati del thesei: i nomi in questo imposti dall'onomaturgo sono thesei, in quanto sono in relazione con la natura delle cose sono physei. Egli ravissa quindi in questa posizione conciliativa la dotrina di Platone, espressa da Socrate nal Cratilo, e di Aristotele [...] Dunque la posizione di Basilio e di Gregorio è propriamente la terza, che dal Daniélou è stata definita scientifica. Ma è restrittivo limitare la matrice della dotrina dei Cappadoci ai grammatici, cui piuttosto vanno associati gli stoici, qui esclusi dallo Steinthal. Anzi, dal momento che il

problema è di carattere pretamente filosofico, cercheremo i punti di contatto con lo Stoicismo". ${ }^{33}$

\section{Conclusion}

The Eunomius-Basil dispute shows that in Byzantium already from the first area of its establishment, the linking of theology with philosophy is formed in the foreground-indeed an analogous tendency is observed in the source era also in the 
Neoplatonic School—and that we could easily formulate grounds for Christian Philosophy. Certainly under the proviso that philosophy is placed in the service of theology and used mainly as that reliable material which will lay the foundations with reasoning and imprint with concepts a theoretical dogmatic speculation. And the two theologians, more or less, renew their philosophical speech, in the sense that they insert it-and in part fertilize it-in a new theoretical and cultural pact. We would consequently claim that they contribute, about even from routers differing between them, to formulating a system of categories which have theological meditations and philosophical supports. Its auctoritas (authority) seeks its sanctions in ratio (reason). A little later Gregory of Nyssa will constitute, with particular success, the undertaking in question. So the Byzantine world comes into the cultural foreground and as an encounter between Christian faith and ancient Greek rationalism, a crucial connection, as we have found, for the development of the history of ideas. What remains in every case of research is to locate the sources, indirect or direct from which the Byzantine theologians draw philosophical material, so as to construct, in tangible measure, an objective presentation of the history presentation of the history of philosophy and of its various connections with the rest of the theoretical fields relating to the period from the 4 th to the 15 th century. We estimate that such a presentation would provision also scientific research into the courses of a systematic type of philosophy in an area where it is governed chiefly by presuppositions and references of hidden structure. Suggestively we would mention that personalities such as John of Damascus and Arethas of Caesarea constitute clear examples of the way in which theology advanced to a fertile recovery of philosophy, without diminishing its traditionally moulded regulatory scopes. Besides, they showed how theology as scientia (science) is theoretically feasible, provided that of course it remains within epistemological reasoning only on physical commodities and divine activities and not divine essence.

\section{Bibliography}

Anastos, M. V. "Basil's Kata Eunomiou. A critical analysis". Basil of Caesarea. Christian, Humanist, Ascetic. Edited by P. J. Fedwick, 67-136. Toronto: Institute of Medieval Studies, 1981.

Bartelink, G. J. M. "Observations de saint Basile sur la langue biblique et théologique”. Vigiliae Christiane 17 (1963): 85-104.

Beardsley, M. C. Aesthetics. Indianapolis: Hackett, 1958.

Cavalcanti, E. Studi eunomiani. Roma: Pontificium Institutum Orientalium Studiorum, 1976.

Cornford, F. M. Plato's Theory of Knowledge. London: Kegan Paul, 1957.

Dams, Th. La controverse eunomenne. Paris: Catholic Institute of Paris, 1952.

Danielou, J. "Eunome l'arien et l'exégèse néo-platonicienne du Cratyle". Revue des Itudes Grecques 69 (1956): 412-452. 
DelCogliano, Mark. Basil of Caesarea's Anti-Eunomian Theory of Names: Christian Theology and Late-Antique Philosophy in the Fourth-Century Trinitarian Controversy. Leiden: Brill, 2010.

DelCogliano, Mark, and Andrew Radde-Galwitz, eds. St. Basil of Caesarea. Against Eunomius. Washington, DC: The Catholic University of America Press, 2011.

Gilson, Et. Christianisme et Philosophie. Paris: J. Vrin, 1986.

Moutsopoulos, Evanghılos. "Ipinoia et imaginaire chez Gregoire de Nysse" (CE II 172-195). Gregory of Nyssa: Contra Eunomium II. Edited by Lenka Karfukova, Scot Douglass and Johannes Zachhuber. Leiden: Brill, 2007, 363-375.

Kalligas, Paul. "Basil of Caesarea on the Semantics of Proper Names". Katerina Ierodiakonou. Edited by Byzantine Philosophy and its Ancient Sources, 31-48. Oxford: Oxford University Press, 2004.

Lossky, J. The Vision of God. Translated by John Meyendorff. London: The Faith Press, 1973.

Martzelos, G. Ousiai kai energeiai tou Theou kata ton Megan Basileion [Essences and Actions of God according to Basil the Great]. Thessaloniki: Pournaras Editions 1993.

Nagel, Thomas. The View from Nowhere. Oxford: Oxford University Press, 1986.

Orbe, A. La Epinoia. Algunos preliminares historicos de la distinction kat' epinoian. Roma: Owen, E. C. E. "Epinoeō, epinoia and allied Words". JThSt 35 (1934): 368-376. Pontifical Gregorian University, 1955.

Panagopoulos, G. D. Stoic Philosophy in the Theology of Basil the Great [in Greek]. Thessaloniki: Herodotos Editions, 2006.

Piguet, J.-Claude, and Gabriel-Ph. Widmer. Le renversement sémantique. Dialogue d'un théologien et d'un philosophe. Paris: Revue de théologie et de philosophie, 1991.

Radde-Galwitz, Andrew. Basil of Caesarea, Gregory of Nyssa, and the Transformation of Divine Simplicity. Oxford: Oxford University Press, 2009.

Rousseau, Philip. "Basil of Caesarea, Contra Eunomium. The main preoccupations: The idea of salvation". The Idea of Salvation. Edited by D. W. Dockrill and R. G. Tanner. Newcastle: University of New England Press, 1988, 77-94.

Sesboóe, Bernard, Georges-Matthieu de Durand, and Louis Doutreleau. Basile de Cusarne Contre Eunome t. I, Sources Chrétiennes, no 299. Paris: Editions du Cerf, 1982.

Troiano, M. S. "I Cappadoci e la questione dell'origine dei nomi nella polemica contro Eunomio". Vetera Christianorum 17 (1980): 313-346.

Uthemann, Karl-Heinz. "Die Sprache der Theologie nach Eunomius vun Cyzicus". Zeitschrift fór Kirchengeschichte 104.2 (1993): 143-175.

Vaggione, Richard Paul. Eunomius. The Extant Works. Oxford: Oxford University Press, 1987.

Vaggione, P. R. Eunomius of Cysicus and the Nicene Revolution. Oxford: Oxford University Press, 2000. 
Vandenbusche, E. "La part de la dialectique dans la théologie d'Eunomius 'le technologue". Revue d'Histoire Ecclésiastique 40 (1944/45): 47-72.

PERICHORESIS $11.1(2013)$ 